\title{
Gel et dégel de la Terre boule de neige néoprotérozoïque : du terrain aux modèles climatiques
}

\section{Freezing and unfreezing of the Neoproterozoic snowball Earth: From field evidence to climate models}

\section{Avant-propos}

L'abondance des sédiments glaciogéniques néoprotérozoïques a conduit Harland et Rudwick [5] à proposer l'existence d'une « grande glaciation infracambrienne » faisant suite à une longue période de plus d'un milliard d'années, durant laquelle le climat de la Terre semble être resté clément. À la fin du siècle dernier, les données paléomagnétiques obtenues à partir de ces sédiments ont révélé des paléolatitudes basses, suggérant que des glaciers de basse altitude s'étendaient jusqu'à l'équateur. La Terre complètement englacée aurait alors ressemblé, vue de l'espace, à une boule de neige, image très évocatrice due à Kirschvink [10]. La Terre boule de neige néoprotérozoïque a suscité alors des débats très vifs dans la communauté scientifique, notamment à la suite des publications majeures de P.F. Hoffman [6,7].

Comprendre la genèse d'un climat aussi extrême nécessitait une approche pluridisciplinaire allant de l'acquisition des données (sédimentologie, stratigraphie, paléomagnétisme) à la modélisation géochimique et climatique. Ce numéro thématique reflète la diversité des études entreprises dans ce sens entre 2000 et 2007 , sous l'impulsion des programmes ECLIPSE I et II (Étude des climats du passé : histoire et évolution) du CNRS (Centre national de la recherche scientifique, France). Des collaborations internationales, notamment avec le Brésil dans le cadre d'un projet bilatéral CAPES (Coordenação de Aperfeicoamento de Pessoal de Nivel Superior)-Cofecub (Comité français d'évaluation de la

\section{Foreword}

Based on the abundance of Neoproterozoic glacial deposits, Harland and Rudwick [5] pointed out the existence of a 'great Infra-Cambrian glaciation' after one billion years of mild climate. The palaeomagnetic data derived from these sediments at the end of the 20th century yielded low palaeolatitudes, suggesting that the ice at sea level may have extended down to the equator. Thus, the ice-covered Earth would have looked like a snowball from space, a striking image due to Kirschvink [10]. The Neoproterozoic snowball Earth hypothesis has been debated so far, especially since Hoffman's seminal papers [6,7].

Understanding such an extreme climatic event required a multidisciplinary approach, implying collection of new sedimentary, stratigraphic and palaeomagnetic data as well as numerical geochemical and climate modelling. This thematic issue mirrors the diversity of studies undertaken between 2000 and 2007, with the support of ECLIPSE I and II ('Étude des climats du passé : histoire et évolution') programs of the French CNRS ('Centre national de la recherche scientifique'). Collaborative work with scientists from abroad has also been active and the support of the Brazilian-French CAPES ('Coordenação de Aperfeicoamento de Pessoal de Nivel Superior')-COFECUB ('Comité français d'évaluation de la coopération universitaire avec le Brésil') program from 2004 to 2007 is worth noticing.

This thematic issue is equally devoted to the onset and the demise of the Neoproterozoic glaciations. 
coopération universitaire avec le Brésil) entre 2004 et 2007 ont contribué aussi à l'avancement des travaux.

$\mathrm{Ce}$ fascicule traite également de l'entrée en glaciation et de la déglaciation, cette dernière ne posant pas moins de problèmes du fait de l'albedo terrestre, très élevé dans l'éventualité d'une glaciation globale. Partout dans le monde, on peut observer des carbonates très particuliers, qui font généralement suite aux dépôts glaciogéniques. Ces cap carbonates représentent les dépôts de la transgression postglaciaire. Ils ont des caractères sédimentologiques et isotopiques spécifiques, demeurés encore mal compris jusqu'à présent. Ces successions sédimentaires évoquent des changements climatiques rapides, que l'on tente ici de modéliser.

L'ancrage dans les données de terrain est indispensable. Des exemples omanais, norvégien, namibien, nord-américain, australien et brésilien [1,4,7-9,13], entre autres, ont déjà été décrits en détail et servent souvent de référence. Ce fascicule met l'accent sur d'autres terrains tout aussi représentatifs ; deux exemples proviennent $\mathrm{du}$ craton ouest-africain [12,15], les deux autres du craton de Congo-São Francisco [14,18].

Shields et al. [15] se sont consacrés à la bordure sud-ouest du bassin de Taoudeni, en Afrique de l'Ouest. La succession lithostratigraphique de la vallée de Walidalia commence par une diamictite déposée au front d'un glacier littoral, suivie de faciès glacio-marins plus distaux, tels que des argilites à blocs lâchés, qui passent ensuite à des grès grossiers sous influence fluviatile. La grande transgression régionale qui leur fait suite se traduit par des dépôts dolomitiques, comparables aux cap dolomies postglaciaires typiques décrites en d'autres endroits du monde. L'ensemble évoque un retrait des glaciers dans un contexte glacio-marin proximal, affecté par les phénomènes glacio-eustatiques.

Trindade et Macouin [16] font le point sur les données paléomagnétiques et géochronologiques existantes, pour l'intervalle de temps compris entre 750 et $550 \mathrm{Ma}$. C'est une revue indispensable pour apprécier quantitativement et qualitativement les fondements de l'hypothèse de la Terre boule de neige néoprotérozoïque. Force est de constater aujourd'hui que plusieurs résultats acquis en différentes régions du globe attestent des conditions glaciaires à basse latitude et confortent donc l'hypothèse initiale de Kirschvink [10]. Trois glaciations au moins sont maintenant identifiées à la fin du Précambrien, et leurs âges sont relativement assurés : la glaciation sturtienne $(\sim 715 \mathrm{Ma} \pm 30 \mathrm{Ma})$, la glaciation marinoenne $(\sim 635 \mathrm{Ma})$ et la glaciation varangi-
Indeed, how to escape from a global glaciation with a very high albedo is as questionable as how to enter into. Carbonates overlie the glacigenic deposits worldwide, and are regarded as the sediments deposited during the post-glacial transgression. Such 'cap carbonates' display peculiar sedimentary and isotopic features, which have not been satisfactorily explained so far. These sedimentary successions are evocative of fast climate changes, hereafter numerically simulated.

Field data are the base of any further work. Reference areas, such as Oman, Svalbard, Namibia, western North America, Australia and Amazonia, among others, have been extensively detailed $[1,4,7-9,13]$. This issue provides thorough studies of other representative areas, two from the West African craton [12,15], and the two others from the Congo-São Francisco craton [14,18].

The first paper, by Shields et al. [15], is dedicated to the southwestern part of the Taoudeni Basin (West Africa). The lithostratigraphic succession of the Walidalia Valley begins with a diamictite deposited in front of a partially grounded ice sheet, overlain by more distal sediments, then followed by fluvially influenced sandstones. Upsection, a transgressive unit consists of typical cap dolostones. This succession closely resembles facies related to glacial retreat in a proximal glaciomarine environment affected by glacioeustasy.

Trindade and Macouin [16] browse a review of the existing palaeomagnetic and geochronological data for the 750-550-Ma time interval. This is the founding database of the Neoproterozoic snowball Earth hypothesis. In this updated version, several independent data from various part of the world provide evidence of ice deposition at low latitudes, hence supporting Kirschvink's hypothesis [10]. At least three glaciations are currently recognized: the Sturtian or Rapitan $(\sim 715 \mathrm{Ma} \pm 30 \mathrm{Ma})$, the Marinoan or Elatina $(\sim 635 \mathrm{Ma})$, and the Varanger or Gaskiers $(\sim 580 \mathrm{Ma})$ ice ages. In addition, the authors provide palaeogeographic reconstruction maps for three relevant times of the Neoproterozoic. These maps are constrained by palaeomagnetic, geochronological and geological data and can be used for climate modelling.

Goddéris et al. [3] investigate the mechanisms that might have triggered a global glaciation. They use a coupled geochemical-climatic model (GEOCLIM), with a spatial resolution of latitude $10^{\circ} \times$ longitude $50^{\circ}$. The model allows the simultaneous calculation of atmospheric $\mathrm{pCO}_{2}$ together with temperature and continental run off. It shows that the rifting and drifting of the supercontinent Rodinia between 800 and $750 \mathrm{Ma}$ was responsible for a $8{ }^{\circ} \mathrm{C}$ global cooling, illustrating that the continental configuration plays a critical role. 
enne ( $~ 580 \mathrm{Ma})$. La synthèse des données paléomagnétiques, géologiques et géochronologiques permet à Trindade et Macouin [16] de proposer des cartes paléogéographiques pour trois moments-clés du Néoprotérozoïque. Ces cartes sont indispensables pour la réalisation des modèles climatiques.

Goddéris et al. [3] évaluent les mécanismes susceptibles de conduire à une glaciation globale. Leur approche consiste à coupler un modèle de cycle du carbone avec un modèle climatique dont la résolution spatiale est de $10^{\circ}$ en latitude et $50^{\circ}$ en longitude. Ce modèle (GEOCLIM) permet le calcul simultané de la teneur en $\mathrm{CO}_{2}$ de l'atmosphère et des paramètres climatiques (température et ruissellement continental). Il indique que la dislocation de la Rodinia entre 800 et $750 \mathrm{Ma}$ provoque un refroidissement global de $8{ }^{\circ} \mathrm{C}$, illustrant le rôle critique de la distribution des continents. La consommation du $\mathrm{CO}_{2}$ atmosphérique est optimisée lorsque les continents se situent dans la zone équatoriale, et surtout si l'on envisage l'altération des grandes provinces basaltiques, épanchées peu avant la fragmentation du supercontinent. Le déclenchement d'une glaciation globale, qui pourrait correspondre à la glaciation sturtienne, est alors possible. Une simulation réalisée avec la majorité des continents au pôle sud, comme à l'époque de la glaciation varangienne (ou Gaskiers ( $580 \mathrm{Ma})$, induit aussi une glaciation, mais celle-ci n'a qu'une amplitude régionale.

Il est à noter d'ailleurs que seules les glaciations sturtienne et surtout marinoenne sont suivies par le dépôt de cap carbonates ubiquistes qui représenteraient donc les sédiments caractéristiques de la fin d'une glaciation globale. Nédélec et al. [12] montrent que les cap dolomies postglaciaires du bassin des Volta au Ghana sont des dépôts péritidaux de climat chaud et relativement aride. Les teneurs en éléments traces témoignent d'un sédiment anoxique où la sulfatoréduction bactérienne a pu favoriser la précipitation de dolomicrite primaire, comme on l'observe aujourd'hui dans certaines lagunes hypersalines du Brésil [17]. Ce modèle génétique bio-induit est compatible avec la signature négative des isotopes du carbone, typique des cap dolomies néoprotérozoïques.

Vieira et al. [18] présentent une étude sédimentologique et stratigraphique approfondie de carbonates réputés postglaciaires de la région de Sete Lagoas (Minas Gerais, Brésil). Deux mégacycles régressifs sont identifiés. Le premier commence par des dépôts de plate-forme profonde, caractérisés par des valeurs négatives de $\delta^{13} \mathrm{C}$ et par la présence de nombreux éventails de cristaux (pseudomorphes d'aragonite), qui ont précipité sur le plancher sous-marin. Ces cristaux,
Consumption of $\mathrm{CO}_{2}$ is enhanced when the continents are located in the equatorial area and especially in places where they are covered by highly weatherable pre-break-up large basaltic provinces. Thus, the model simulates the initiation of a global glaciation, which could correspond to the Sturtian one. A second simulation with most continents at high southern latitudes (a possible situation at the time of the Varanger or Gaskiers glaciation at $\sim 580 \mathrm{Ma}$ ) also initiates a glaciation, but of regional extension.

Besides, only the Sturtian and, especially, the Marinoan ice ages are followed by the deposition of ubiquitous cap carbonates. The cap carbonates are therefore regarded as the typical deposits of the aftermath of a global glaciation. Nédélec et al. [12] show that the cap dolostones from the Volta Basin in Ghana represent peritidal sediments deposited in a warm and rather dry climate. Trace element contents point to anoxic conditions in the sediment, where bacterial sulphate reduction may have favoured the formation of primary dolomicrite. A possible modern analogue is represented by some hypersaline lagoons from Brazil [17]. This microbially induced model is consistent with the negative carbon isotope signatures typical of the Neoproterozoic cap dolostones.

Vieira et al. [18] present a detailed sedimentological and stratigraphic study of likely post-glacial carbonates from the Sete Lagoas area (Minas Gerais, Brazil). Two shallowing-upward megacycles are identified. The first one contains deep-platform deposits, characterized by negative $\delta^{13} \mathrm{C}$ values and abundant crystals fans (pseudomorphs of aragonite precipitates). These aragonite crystals are commonly described in cap carbonates worldwide and are regarded as the result of a calcium-carbonate supersaturation event in the post-glacial ocean [2]. During the second megacycle, a new transgression deposited organic-matter-rich limestones, characterized by positive $\delta^{13} \mathrm{C}$ values (up to $+14 \%$ ). A post-Sturtian age of the Sete Lagoas formation is consistent with carbon chemostratigraphy.

Poidevin [14] attempts a new stratigraphy of the Neoproterozoic platform carbonates and glacial deposits preserved along the Congo craton in the Democratic Republic of Congo (DRC) and in the Central African Republic (CAR). Based on Sr chemostratigraphy, postSturtian or post-Marinoan ages are attributed to different carbonate units. The resulting correlations imply that the 'Bas Congo' lower tillite and the Akwokwo tillite (DRC) were deposited during the Sturtian ice age, and the 'Bas Congo' upper tillite (DRC) and the Bondo tillite (Bakouma, CAR) during the Marinoan ice age. This paper, like the previous one by Vieira et al. [18], 
fréquemment observés dans les cap carbonates, seraient les témoins d'un événement de sursaturation en carbonate de calcium de l'océan postglaciaire [2]. Au cours du second mégacycle, une nouvelle transgression conduit à des dépôts carbonatés riches en matière organique et présentant des valeurs de $\delta^{13} \mathrm{C}$ exceptionnellement positives (jusqu'à $+14 \%$ ). La chimiostratigraphie du carbone permet de proposer un âge postSturtien pour la formation de Sete Lagoas.

Poidevin [14] propose une nouvelle stratigraphie synthétique concernant les témoins de plates-formes carbonatées et d'épisodes glaciaires néoprotérozoïques qui ceinturent le craton du Congo en république démocratique du Congo (RDC) et en République centrafricaine (RCA). La stratigraphie isotopique du strontium permet de préciser la période de dépôt de certaines unités carbonatées, qui sont donc attribuées respectivement au post-Sturtien et au post-Marinoen. Les corrélations lithostratigraphiques qui en découlent impliquent que la tillite inférieure du bas Congo et celle de l'Akwokwo (RDC) sont des témoins de la glaciation sturtienne, tandis que la tillite supérieure du bas Congo et la tillite de la Bondo (Bakouma, RCA) correspondent à la glaciation marinoenne. Cet article et celui de Vieira et al. [18] illustrent la nécessité d'études chimiostratigraphiques approfondies pour parvenir à dater les sédiments précambriens.

Il y a un consensus sur la nécessité d'un effet de serre très marqué pour sortir d'une glaciation globale où l'albédo de la Terre toute blanche s'oppose à la déglaciation. L'accumulation de $\mathrm{CO}_{2}$ d'origine volcanique dans l'atmosphère doit atteindre un seuil critique très élevé, mais dont la valeur est discutée et peut dépendre des modèles utilisés. Ainsi, Le Hir et al. [11] testent la sensibilité de deux modèles de circulation atmosphérique générale (FOAM et $\mathrm{LMDz}$ ), partant d'un équilibre glaciaire atteint à 100 ppmv de $\mathrm{CO}_{2}$ dans la configuration équatoriale sturtienne. Aux fortes teneurs en $\mathrm{CO}_{2}(0,1 \mathrm{bar})$, les températures estivales obtenues sont de $255 \mathrm{~K}$ avec FOAM et de $270 \mathrm{~K}$ avec LMDz. Cet écart est dû à un forçage radiatif des nuages plus important dans le modèle LMDz, en relation avec un cycle hydrologique résiduel, actif dans l'hémisphère d'été aux moyennes latitudes. Ainsi, suivant les schémas convectifs retenus, on peut obtenir différents seuils de déglaciation. Les simulations de Le Hir et al. [11] indiquent qu'une déglaciation est possible à partir d'une pression partielle de $\mathrm{CO}_{2}$ de 0,2 bar (ou même moins) dans l'atmosphère.

Nous espérons que cet ensemble d'articles permettra une meilleure compréhension des climats extrêmes qui caractérisent la fin du Précambrien et qui ont pu illustrates how a detailed chemostratigraphy can be used to date these Precambrian sediments.

There is a consensus that only a very strong greenhouse effect could overwhelm the cooling feedback of the high albedo of a white snowball Earth, thus providing a way to escape from a global glaciation. The building of a $\mathrm{CO}_{2}$-rich atmosphere is due to continuous volcanic degassing. Nevertheless, the melting threshold is debated and may also be model-dependent. Le Hir et al. [11] test the sensitivity of two atmospheric circulation models (FOAM and LMDz). The simulations begin with a glacial environment in equilibrium with $100 \mathrm{ppmv} \mathrm{CO}_{2}$ in the atmosphere, and use a Sturtian palaeogeography. When high $\mathrm{CO}_{2}$ values (up to 0.1 bar) are reached, the resulting summer temperatures are $255 \mathrm{~K}$ with FOAM and $270 \mathrm{~K}$ with LMDz. The difference is due to a more efficient radiative forcing of nebulosity in LMDz, in relation to the residual hydrological cycle that remains active in the mid-latitudes of the summer hemisphere. Hence, different convection schemes may provide different deglaciation thresholds. The results of Le Hir et al. [11] suggest a melting threshold for atmospheric $\mathrm{pCO}_{2}$ of 0.2 bar, or even less.

We hope that this set of new papers will provide a better understanding of the extreme climates that occurred at the end of Precambrian times and might have influenced life evolution in the meantime [19]. Hazard or causality? Sorting out the interactions between geological and biological events is the big challenge for future research.

At last, we are glad to cite all the reviewers that contributed to the preparation of this thematic issue: E. Arnaud, M. Babinski, M. Brasier, F. Fluteau, J. Gaillardet, C. Gaucher, Y. Goddéris, G. Halverson, W. Hyde, A. Knoll, M. Renard, G. Shields, L. Tack, and N. Tribovillard. C. Cavaré-Hester improved the cover illustration as well as many other drawings. M. Grandin-Jimenez and H. Paquet provided a precious help in the final setting of the manuscripts. Our sincere thanks go to all of them.

Anne Nédélec

LMTG - UMR 5563 - OMP université Toulouse-3, France Email address: nedelec@lmtg.obs-mip.fr

Gilles Ramstein LSCE, CNRS-CEA Gif-sur-Yvette, France

Jacques Laskar IMCCE Paris, France

Available online 2 April 2007 
influencer l'évolution de la vie à cette période [19]. Hasard ou causalité ? Révéler les relations possibles entre les événements géologiques et biologiques est un champ d'investigations largement ouvert pour les recherches futures.

Pour terminer, il nous faut citer tous les lecteurs qui ont contribué à la préparation de ce numéro thématique : E. Arnaud, M. Babinski, M. Brasier, F. Fluteau, J. Gaillardet, C. Gaucher, Y. Goddéris, G. Halverson, A. Knoll, M. Renard, G. Shields, L. Tack et N. Tribovillard. C. Cavaré-Hester a amélioré l'illustration de couverture et plusieurs autres dessins. Ce numéro n'aurait pas pu être mené à son terme sans le dévouement de M. Grandin-Jimenez et H. Paquet. À tous, nous adressons nos sincères remerciements.

Anne Nédélec
$L M T G-U M R 5563-$ OMP université Toulouse-3,
France
Adresse e-mail : nedelec@1mtg.obs-mip.fr
Gilles Ramstein
LSCE, CNRS-CEA Gif-sur-Yvette, France
Jacques Laskar
IMCCE Paris, France

Disponible sur Internet le 2 avril 2007

\section{Références}

[1] P. Allen, J. Leather, M.D. Brasier, The Neoproterozoic Fiq glaciation and its aftermath, Huqf Supergroup of Oman, Basin Res. 16 (2004) 507-534.

[2] F. Corsetti, N. Lorentz, S. Pruss, Formerly-aragonite seafloor fans from Neoproterozoic strata, Death Valley and southeastern Idaho, United States: implications for cap carbonates formation and Snowball Earth, in: G. Jenkins, M. McMenamin, C. McKay, L. Sohl (Eds.), The extreme Proterozoic: geology, geochemistry and climate, Geophys. Monogr. Ser. 146, American Geophysical Union, Washington D.C., 2004, pp. 33-44.

[3] Y. Goddéris, Y. Donnadieu, C. Dessert, B. Dupré, F. Fluteau, L.-M. François, J. Meert, A. Nédélec, G. Ramstein, Coupled modeling of global carbon cycle and climate in the Neoproterozoic: links between Rodinia breakup and major glaciations, C. R. Geoscience 339 (2007).

[4] G.P. Halverson, A.C. Maloof, P.F. Hoffman, The Marinoan glaciation (Neoproterozoic) in Northeast Svalbard, Basin Res. 16 (2004) 297-324.
[5] W.B. Harland, M.S. Rudwick, The great infra-Cambrian ice-age, Sci. Am. 211 (1964) 28-36.

[6] P.F. Hoffman, A.J. Kaufman, G.P. Halverson, D.P. Schrag, A Neoproterozoic snowball Earth, Science 281 (1998) 13421346.

[7] P.F. Hoffman, D.P. Schrag, The snowball Earth hypothesis: testing the limits of global change, Terra Nova 14 (2002) $129-155$.

[8] N.P. James, G.M. Narbonne, T.K. Kyser, Late Neoproterozoic cap carbonates: Mackenzie Mountains, northwestern Canada: precipitation and global glacial meltdown, Can. J. Earth Sci. 38 (2001) 1229-1262.

[9] M.J. Kennedy, Stratigraphy, sedimentology and isotopic geochemistry of Australian Neoproterozoic postglacial dolostone: deglaciation, $\mathrm{C}^{13}$ excursions and carbonate precipitation, J. Sediment. Res. 66 (1996) 1050-1064.

[10] J.L. Kirschvink, Late-Proterozoic low-latitude global glaciation: the snowball Earth, in : J.W. Schopf, C. Klein (Eds.), The Proterozoic Biosphere, Cambridge University Press, 1992, pp. 51-52.

[11] G. Le Hir, G. Ramstein, Y. Donnadieu, R.T. Pierrehumbert, Investigating plausible mechanisms to trigger a deglaciation from a hard snowball Earth, C. R. Geoscience 339 (2007).

[12] A. Nédélec, P. Affaton, C. France-Lanord, A. Charrière, J.J. Alvaro, Sedimentology and chemostratigraphy of the Bwipe Neoproterozoic cap dolostones (Ghana, Volta Basin): a record of microbial activity in a peritidal environment, C. R. Geoscience 339 (2007).

[13] A.C.R. Nogueira, C. Riccomini, A.N. Sial, C.A.V. Moura, T.R. Fairchild, Soft-sediment deformation at the base of the Neoproterozoic Puga cap carbonate (southwestern Amazon craton, Brazil): confirmation of rapid icehouse to greenhouse transition in snowball Earth, Geology 31 (2003) 613-616.

[14] J.-L. Poidevin, Stratigraphie isotopique du strontium et datation des formations carbonatées et glaciogéniques néoprotérozoïques du Nord et de l'Ouest du craton du Congo, C. R. Geoscience 339 (2007).

[15] G.A. Shields, M. Deynoux, S.J. Culver, M.D. Brasier, P. Affaton, D. Vandamme, Neoproterozoic glaciomarine and cap dolostone facies of the southwestern Taoudéni Basin (Walidiala Valley, Senegal/Guinea, NW Africa), C. R. Geoscience 339 (2007).

[16] R.I.F. Trindade, M. Macouin, Paleolatitude of glacial deposits and palaeogeography of Neoproterozoic ice ages, C. R. Geoscience 339 (2007).

[17] C. Vasconcelos, J.A. Mackenzie, Microbial mediation of modern dolomite precipitation and diagenesis under anoxic conditions (Lagoa Vermelha, Rio de Janeiro, Brazil), J. Sediment. Res. A67 (1997) 378-390.

[18] L.C. Vieira, R.I.F. Trindade, A.C.R. Nogueira, M. Ader, Identification of a Sturtian cap carbonate in the Neoproterozoic Sete Lagoas carbonate platform, Bambuí Group, Brazil, C. R. Geoscience 339 (2007).

[19] S. Xiao, A.J. Kaufman, Neoproterozoic geobiology and palaeobiology, Springer, Dordrecht, The Netherlands, 2006, 300 pp. 